\title{
CRITICAL THINKING IN DIGITAL NATIVES: A DOCTORAL RESEARCH THROUGH A NEW TAXONOMY
}

\author{
Maria Caterina De Blasis \\ Department of Education, University of Roma Tre (Italy)
}

\begin{abstract}
How to define and how to measure critical thinking (CT)? This paper presents the first findings of a PhD research project that, in its first part, has seen an in-depth desk analysis and aims to outline which traits of CT are needed by "digital natives" in the context of the fourth industrial revolution. Starting from the need to clarify whether it makes sense to speak about "digital natives" and analysing the changes in the labour market and society, increasingly influenced by digital disruption, this research work intends to underline the importance of CT in a world that appears more and more shaped by technology. The domain of CT, in facts, will allow people to distinguish itself from machines, recreate a balance "pro human" and reduce possible environmental problems. The desk research has led to outline 10 characteristics of CT (merged into a taxonomy of the major CT fields) in the areas of school, work and society, "translated" into a questionnaire submitted to a sample of Italian students. The sample has been chosen among philosophy students and others that do not study this subject, to assess whether the teaching of philosophy contributes to the development of CT. Since it is difficult to predict clearly the future of work, preparing students for future life means giving them self-mastery. The guiding hypothesis of the research, therefore, is that the development of CT can help young generations to promote their own "agency" that supports them in continuous evolution environments (both scholastic and not) and allows them to make their talents bloom, starting from the freedom of action and choice. So the promotion of people's potential becomes as central as the development of a "capability approach", to allow each person, both individually and collectively, to develop their own makings and have reasonable chances of leading a productive and creative life.
\end{abstract}

Keywords: Critical thinking, digital natives, fourth industrial revolution, agency, capability approach.

\section{Introduction}

The important technological and digital changes of the last decades have led to a real industrial revolution that appears to be characterized by strong uncertainties, but also by an equally clear message. «The fourth industrial revolution - Schwab says - does not only change what we do, but also what we are: those who do not embrace change are likely to come out defeated» (Schwab, 2016b). Thus, there are not only critical issues, but also opportunities that involve both production systems and education. The latter needs to be ready for the changes that can become challenges not to undergo the digital transformation, but to govern it.

In education research, since a few years some researchers have been talking about learning "across spaces" (Looi, 2009) which, associated with new generation technologies (smartphones and tablets, but even wearable technologies), returns scholastic experiences no longer subject to space-time limits. It is therefore possible to learn and train in different environments, virtual or real, that we can consider almost "non-places" or "liminal places", no longer limited to school classrooms. In fact, new technologies carry, in the classic learning places, codes and languages typical of the instruments used extra moenia. In this rapidly evolving context, "digital natives" (Prensky, 2001) are learning. Grown up using a wide variety of technological devices since early childhood, they may have acquired particular skills, abilities and, consequently, possible new learning strategies. The Prensky's fortunate definition has had also some criticisms from those who questioned the real presence of a "digital generation" (Bennett et al., 2008) or argued that digital natives are actually just a myth (Kirschner, De Bruyckere, 2017). The hypothesis is that "iGen" students know digital world not in a homogeneous or innate manner. They limit themselves to a mostly passive and opportunistic use of the new digital tools, proving to be able to use technology, but without a real knowledge to support one's own learning, highlighting, in this way, just a familiarity and not a technological awareness (Iannella A. et al., 2017). The PISA-OECD surveys show that Italian students are below average for "web surfing oriented activities", so much so that the Ministry of Education calls 
them "lost in navigation" (MIUR, 2016). If that of digital natives is really just a myth, it follows that even learning projects based on it (for example using only a technology-assisted didactics) would risk making their education slower and more difficult, as the overexposure to stimuli would impede the effectiveness of learning (Kirschner, De Bruyckere, 2017). The core issue is not only having access keys to surf the Internet, but also knowing how to surf intelligently and profitably. «Many young people [...] do not have the ability to direct their own reading, to make judgments about the relevance of a web page or the quality of an argument. They click on what moves and are not selective [...], they do not go directly to the information they are looking for, whereas they should show themselves to be critical consumers of online information, whose quality is far from being uniform» (MIUR 2016, p.11). Nevertheless how can they be or become "critical consumers"?

\subsection{Critical consumers alias critical thinkers}

Once in front of media contents, digital natives often risk being "grasshopper minds" (Pedró 2009, p.18): they have an inclination to leap quickly from one topic to another, they are not constant and impatient if sources of information are not immediately at their fingertips. They have difficult to lingering over a subject and they are inclined to give priority to images, videos and music over text (Ibidem). Instead, situations and complex problems require more attention and, above all, a more complex reasoning, a more careful thought that can reformulate the issues and deepen into them, avoiding conclusions «too rushed, in which the ambiguities of language are not resolved or in which our personal inclinations are too much influential» (Colasanti, 2012, p.21). The digital natives' thought should then be "disciplined", so that students can question the validity of arguments, discover possible errors of reasoning and logic, analyse the reliability of a source, identify implicit or explicit assumptions of an argument or an information (Ranieri, 2007). The "iGen" young should therefore be critical thinkers inclined not simply to think. The simple, natural process of thinking, in fact, if not reasoned, educated or trained, can be biased, distorted, partial, misinformed and even potentially prejudicial (Scriven and Paul, 2004). Instead, the critical thinker is able not only to think, but also to try to "get it right". He can articulate an opinion clearly and honestly, he takes into account other people's ideas and he is able to take care of others' thoughts. He is then able to seek, clarify and appropriately judge the assumptions to develop his own point of view; can intelligently argue from given bases; can suppose and integrate an idea (even with originality and imagination). All of this «with dispatch, sensitivity, and rhetorical skill» (Ennis 2011, p.5).

Although it is difficult to trace a shared definition of CT, among the descriptions that in recent years have had the greatest follow-up, there is undoubtedly the Facione's one, who undertands it as follows:

«We understand critical thinking to be purposeful, self-regulatory judgment which results in interpretation, analysis, evaluation, and inference, as well as explanation of the evidential, conceptual, methodological, criteriological, or contextual considerations upon which that judgment is based. CT is essential as a tool of inquiry. As such, CT is a liberating force in education and a powerful resource in one's personal and civic life» (Facione 1990, p.2).

CT, however, cannot be restricted to predefined frames or locked up within the rigid boundaries of a definition (even the Latin etymology of the term refers precisely to the idea of border that in Latin was called "finis"). CT is, in fact, free thinking that feeds on questions and problems and therefore, rather than being limited within the confines of a definition, can be described through categories with less rigid outlines that embrace not only the world of school that digital natives inhabit today, but also the labour environments they will inhabit tomorrow.

\subsection{The importance of being critical thinkers in a changing world}

The digital transformation's changes obviously do not concern only the educational institutions, but also the labour market in which new skills are sought. The 2016 data of the World Economic Forum tell us that $65 \%$ of children entering primary school today will ultimately end up working in completely new job types that do not yet exist and that, obviously, will strong undergo digital influence. Those who now sit behind school desks must therefore develop transversal skills to be used in a labour market that, at this moment, appears only conceivable. Future workers should have skills useful for facing the challenges of an environment that is changing rapidly and, likewise, requires people new knowledge and skills to adapt and deal, in a competent manner, with highly diversified situations. Even if the ability to think and reason independently can seem superfluous if all we are looking for is quantifiable in "business" terms (Nussbaum, 2011), even the world of work needs critical thinkers.

The European Commission report, "10 trends. Transforming education as we know it" (2017), remembers us that humans are not the only ones learning and that, to gain novel insights, we will increasingly compete with machines. «Advances in high-performance computing are enabling an artificial intelligence revolution whereby machines can learn and take on ever more complex tasks» (EU 2017, p.3). People could find themselves increasingly competing with robots (no longer only on routine tasks and lowskill jobs) and so we have to revalue and strengthen the skills that once already had been central to human 
species' success, such as creativity, problem solving, negotiation, adaptability, working together, cross cultural communication, empathy and emotions, critical thinking. Precisely to this latter competence, the European Political Strategy Center dedicates particular attention considering it a fundamental pillar also to face the consensus' creation through fake news.

CT also occupies a central position in the recent report of the World Economic Forum, "Towards a Reskilling Revolution. Industry-Led Action for the Future of Work" (2019), which highlights how employers consider most important today, as well as expected to be trending by 2022, not only digital skills (like technology design and programming and systems analysis and evaluation), but also "human" ones. Among these, we can find exactly CT that, like creativity, initiative, leadership, is not expected to be automated in the near future.

At the same way, the International Labour Organization, starting from the assumption that technological changes will bring flexibility and autonomy, but also an unclear future with uncertainty and insecurity, speaks about "core skills" on which young workers (high-, medium- and low skilled) will need training on: adaptability, social intelligence, creativity, imagination, social and communication skills, critical reasoning.

The domain of $\mathrm{CT}$, therefore, together with other cross skills, will allow human beings to distinguish themselves from robotic and technological devices that in the coming years, with the digitalization of organizations, could replace most of the jobs tasks. The mind, therefore, looks just like the adaptive "tool" that can deal with the complexity and the problematic nature of the environment and try to reduce or translate it (Dewey 1961, Morin, 2000).

\section{Objectives}

Taking note of the fundamental importance of CT for the fourth industrial revolution students, who will have to apply their knowledge in changing and, for the most part, unknown world, this research project was born with two macro objectives:

a) To study digital natives in their learning environments, verifying whether they use CT both in learning and in using digital devices.

b) To verify if, in digital natives, CT is more developed and encouraged through the study of philosophy.

In this context, the teaching of philosophy is understood as the promotion of the counterfactual that can train students' ability to imagine other possible worlds. In this way, they could find solutions to problems, concrete or abstract, following a path that starts from reflection and arrives at to advance explanations and alternatives, through the discussion and the presentation of one's motivations. Philosophy is considered here as "criticism of criticism" that invokes experience and takes the form of a wisdom capable to influence the conduct of one's life (Dewey, 1968).

Education, indeed, has to maintain a social nature by making students active subjects and protagonists of the processes of learning and forming one's own critical conscience. Already in 1897, Dewey claimed that it would not be possible to predict precisely how civilization would have been like in the years to come. Equally impossible, therefore, it is prepare students for a precise order of conditions. Preparing them for future life, therefore, means giving them self-mastery (Dewey, 2004, p.6).

The guiding hypothesis underlying the present research is that CT can help young generations to promote their own "agency" (Sen 1998, 2001, Nussbaum 2012) that will support them in continuous evolution environments (both scholastic and not) and allow them to change, rethink and retrain their own talent starting from the freedom of action and choice. The agency would allow a necessary cognitive flexibility with the motivation to learn by combining "thought" and "action" and "doing" with "thinking how to do as best as possible" (Costa, 2016).

\section{Methods}

The first part of this research project has seen an in-depth desk analysis aimed to examine both existing Italian and international literature and to analyse studies already conducted about these topics. This first approach has led us to understand how young generations move in their learning environment; use their digital tools for learning and organize times and spaces between online and offline boundaries. It allowed even an analysis on the labour market and social requests regarding CT.

Through the studies conducted, a taxonomy has been realized on the greatest descriptive areas of CT. The taxonomy, composed of 10 indicators (Analysis; Beware of sources; Cognitive and emotional self-regulation; Curiosity; Dialectical approach; Empathy; Imagination and open mind; Reflexivity; Respect; Self-correction), represents an overall view of CT within the fourth industrial revolution and encloses the areas of school, work and society. It has been used also as a road map for the quantitative field research. In fact, it led to the creation of a questionnaire submitted to a sample of Italian students, enrolled 
in the fourth year of high school and chosen between "Liceo" (with philosophy class) and technical institutes (without it).

The questionnaire - which also measures other factors such as digital natives' technological equipment, time dedicated to the use of media content, integration between digital devices and learning method - was used together with the "Questionnaire on the perception of their own skills strategies" (QPCS) (Pellerey et al., 2010). This tool, recognized and validated, encourages the reflection and the awareness of certain specific skills having root in personal qualities, connected with being able to give meaning and perspective to one's own experience and activity. «On the one hand its use allows focusing attention on some aspects of the educational processes often underestimated, or at least not adequately highlighted. On the other hand it allows young people to foster awareness of their knowledge regarding certain fundamental qualities of their act both in the study and in the work» (Pellerey et al., 2013, p.51).

\section{Conclusions}

In the "revolutionary" context of Industry 4.0, the promotion of people's potential becomes, starting from the educational field, increasingly central as the development of a "capability approach", to allow each person, both individually and collectively, to fully develop their own makings and have reasonable chances to lead a productive and creative life (Alessandrini, 2014).

Is therefore necessary an action to encourage the development of CT in digital natives, urging their active participation and their operational involvement.

Since innovation requires flexible, open and creative intelligences (Nussbaum, 2011), it is essential that students cultivate CT as a continuous quest for a global approach to reality and the problems associated with it. In the new "ecosystems" of work (Alessandrini, 2017), what is useful to learn at a certain moment can be quickly overcome. What remains is the ability to read and think critically about what we are facing, because we do not know what we will need to know in the future, but we do know we will need to be skilled in finding out (Elder, Paul, 2007).

\section{References}

Alessandrini, G., (Ed.). (2014). La "pedagogia" di Martha Nussbaum. Approccio alle capacità e sfide educative. Milano: FrancoAngeli.

Alessandrini, G., (Ed.). (2017). Atlante di Pedagogia del Lavoro. Milano: FrancoAngeli.

Bennett, S., \& Maton K., Kervin L. (2008). The 'digital natives' debate: a critical review of the evidence. British Journal of Educational Technology, 39 (5), pp. 775-786.

Colasanti, L. (2012). Pensiero. Che cosa significa pensare? Roma: Gruppo Editoriale L'Espresso.

Colombo, C., \& Donadio A. et al. (2015). The human side of digital. Era digitale, capitale umano, nuovi paradigmi. Milano: Guerini Next.

Costa, M. (2016). Capacitare l'innovazione. La formatività dell'agire lavorativo. Milano: FrancoAngeli.

Dewey, J. (1961). Come pensiamo: una riformulazione del rapporto fra il pensiero riflessivo e l'educazione. Firenze: La nuova Italia.

Dewey, J. (1968). La ricerca della certezza: studio sul rapporto fra conoscenza e azione. Firenze: La Nuova Italia.

Dewey, J. (1999). Le fonti di una scienza dell'educazione. Firenze: La Nuova Italia.

Dewey, J. (2004). Il mio credo pedagogico. Firenze: La Nuova Italia.

Elder, L., \& Paul, R. (2007). White paper. Consequential validity: using assessment to drive instruction. Tomales: Foundation for Critical Thinking.

Ennis, R.H. (1985). A logical basis for measuring critical thinking skills. Educational Leadership, 43, pp. 44-48.

Ennis, R.H. (1991). Critical thinking: a streamlined conception. Charlottesville (VA): Teaching Philosophy.

Ennis, R.H. (2011). The Nature of Critical Thinking: An Outline of Critical Thinking Dispositions and Abilities. Sixth International Conference on Thinking, MIT, Cambridge (MA): July 1994 (Last revised May 2011).

European Commission. (2017). 10 trends. Transforming education as we know it. Bruxelles.

Facione, P.A. (1990). Critical thinking: A statement of expert consensus for purposes of educational assessment and instruction - The Delphi Report. Berkeley, CA: California Academic Press.

Facione, P.A. (2011). Critical Thinking: What It Is and Why It Counts. Millbrae, CA: Measured Reasons and The California Academic Press.

Iannella, A., \& Fiorentino G. et al. (2017). Per una didattica del latino tra conoscenze disciplinari e competenze digitali. Roma: Atti convegno Didamatica. 
International Labour Organization. (2017). Global employment trends for youth 2017. Ginevra.

Kirschner, P.A., \& De Bruyckere, P. (2017). The myths of the digital native and the multitasker. Teaching and Teacher Education, 67, pp. 135-142.

Looi, C.K., \& Wong, L.H. et al. (2009). Anatomy of a mobilized lesson: Learning my way. Computers \& Education, 53(4), pp. 1120-1132.

Ministero dell'Istruzione, dell'Università e della Ricerca. (2016). Studenti, computer e apprendimento: dati e riflessioni. Uno sguardo agli esiti delle prove in Lettura in Digitale dell 'indagine OCSE PISA 2012 e alla situazione in Italia. Roma.

Morin, E. (2000). La testa ben fatta. Milano: Raffaello Cortina.

Nussbaum, M.C. (2011). Non per profitto. Perché le democrazie hanno bisogno della cultura umanistica. Bologna: Il Mulino.

Nussbaum, M.C. (2012). Creare capacità. Liberarsi dalla dittatura del Pil. Bologna: Il Mulino.

OECD. (2018). The future of education and skills. Education 2030. Paris.

Pedró, F. (2009), New millennium learners in higher education: evidence and policy implications. Paris: OECD- CERI.

Pellerey, M. et al. (2010). Promuovere la crescita nelle competenze strategiche che hanno le loro radici nelle dimensioni morali e spirituali della persona. Rapporto di ricerca. Roma: Cnos-Fap.

Pellerey, M. et al. (2013). Imparare a dirigere se stessi. Progettazione e realizzazione di una guida e di uno strumento informatico per favorire l'autovalutazione e lo sviluppo delle proprie competenze strategiche nello studio e nel lavoro. Roma: Cnos-Fap.

Prensky, M. (2001). Digital Natives, Digital Immigrants. On the Horizon, 9(6), pp. 15-24.

Ranieri, M., (Ed.). (2007). Problem solving, pensiero critico, metacognizione, in Calvani, A., (Ed.). Tecnologia, scuola, processi cognitivi. Per una ecologia dell'apprendere. Milano: FrancoAngeli.

Rapetti, E., \& Cantoni, L. (2010). "Nativi digitali” e apprendimento con le ICT. Journal of e-Learning and Knowledge Society, 6 (1), pp. 43-53.

Schwab, K. (2016a). La quarta rivoluzione industriale. Milano: FrancoAngeli.

Schwab, K. (2016b). «Così la $4^{a}$ rivoluzione industriale cambia la nostra vita», intervista a Di Lucchio M. EconomyUp. December 6, 2016.

Scriven, M., \& Paul, R. (2004). The Critical Thinking Community. Tomales: Foundation for Critical Thinking.

Seghezzi, F. (2017). La nuova grande trasformazione. Lavoro e persona nella quarta rivoluzione industriale. Modena: Adapt University Press.

Sen, A.K. (1998). Il tenore di vita. Tra benessere e libertà. Venezia: Marsilio Editore.

Sen, A.K. (2001). Lo sviluppo è libertà. Milano: Mondadori.

World Economic Forum. (2016). The future of jobs report. Cologny.

World Economic Forum. (2019). Towards a Reskilling Revolution. Industry-Led Action for the Future of Work. Cologny. 